\title{
The role of organisms in hyporheic processes: gaps in current knowledge, needs for future research and applications
}

\author{
P. Marmonier ${ }^{1 *}$, G. Archambaud ${ }^{2}$, N. Belaidi ${ }^{3}$, N. Bougon ${ }^{4}$, P. Breil $^{5}$, E. Chauvet ${ }^{6,7}$, C. Claret $^{8}$,
} J. Cornut ${ }^{6,7}$, T. Datry ${ }^{4}$, M.-J. Dole-Olivier ${ }^{1}$, B. Dumont ${ }^{2}$, N. Flipo ${ }^{9}$, A. Foulquier ${ }^{1,4}$, M. Gérino ${ }^{6,7}$, A. Guilpart ${ }^{10}$, F. Julien ${ }^{6,7}$, C. Maazouzi ${ }^{1}$, D. Martin ${ }^{1}$, F. Mermillod-Blondin ${ }^{1}$, B. Montuelle ${ }^{4,11}$, Ph. Namour ${ }^{4,12}$, S. Navel ${ }^{1}$, D. Ombredane ${ }^{10}$, T. Pelte ${ }^{13}$, C. Piscart $^{1}$, M. Pusch $^{14}$, S. Stroffek ${ }^{13}$, A. Robertson ${ }^{15}$, J.-M. Sanchez-Pérez ${ }^{6,7}$, S. Sauvage ${ }^{6,7}$, A. Taleb ${ }^{3}$, M. Wantzen ${ }^{16}$ and $\mathrm{Ph}$. Vervier ${ }^{6,7,17}$

${ }^{1}$ Université de Lyon, Université de Lyon 1, UMR-CNRS 5023 LEHNA, 43 Bd du 11 Novembre1918, F-69622 Villeurbanne Cedex, France

${ }^{2}$ Cemagref Aix-en-Provence, Hydrobiologie-EEC, 13182 Aix-en-Provence Cedex 5, France

3 Département de biologie et environnement, Université de Tlemcen, DZ-13000 Tlemcen, Algeria

${ }^{4}$ Cemagref Lyon, UR MALY, 3bis quai Chauveau, 69336 Lyon Cedex 09, France

5 Cemagref Lyon - UR Hydrologie Hydraulique, 3 bis quai Chauveau, 69336 Lyon Cedex 09, France

${ }^{6}$ Université de Toulouse, UPS, INPT, EcoLab (Laboratoire d'Écologie Fonctionnelle et Environnement), Bât. 4R1, 118 Route de Narbonne, 31062 Toulouse Cedex 9, France

7 CNRS, Ecolab, 31055 Toulouse Cedex 4, France

8 Institut Méditerranéen d'Écologie et de Paléoécologie IMEP, UMR-CNRS 6116, Université Paul-Cézanne Aix-Marseille 3, 13397 Marseille Cedex 20, France

9 École des Mines de Paris, Géoscience Départment, Fontainebleau Cedex, France

10 INR-Agrocampus-Ouest, UMR 985 Écologie et Santé des Ecosystèmes, 65 rue de St Brieuc, 35042 Rennes Cedex, France

11 INRA, UMR CARTEL, Route de Corzent, BP 511, 74203 Thonon-les-Bains, France

12 Université de Lyon, Université Lyon 1, Institut des Sciences Analytiques, UMR 5280, F-69622 Villeurbanne, France

13 Ministère de l'Environnement, Agence de l'Eau Rhône-Méditerrannée and Corse, 2-4 Allée de Lodz, 69363 Lyon Cedex 07, France

14 Leibniz Institute of Freshwater Ecology and Inland Fisheries (IGB), Berlin, Germany

15 Department of Life Sciences - Roehampton University, Holybourne Avenue, London SW15 4JD, UK

16 Université de Tours, UMR 6173 CITERES, Département IMACOF, 33 allée F. de Lesseps, 37204 Tours Cedex 03, France

17 Acceptables Avenirs Prologue, La Pyrénéenne, BP 27201, 31672 Labège Cedex, France

\begin{abstract}
Fifty years after the hyporheic zone was first defined (Orghidan, 1959), there are still gaps in the knowledge regarding the role of biodiversity in hyporheic processes. First, some methodological questions remained unanswered regarding the interactions between biodiversity and physical processes, both for the study of habitat characteristics and interactions at different scales. Furthermore, many questions remain to be addressed to help inform our understanding of invertebrate community dynamics, especially regarding the trophic niches of organisms, the functional groups present within sediment, and their temporal changes. Understanding microbial community dynamics would require investigations about their relationship with the physical characteristics of the sediment, their diversity, their relationship with metabolic pathways, their interactions with invertebrates, and their response to environmental stress. Another fundamental research question is that of the importance of the hyporheic zone in the global metabolism of the river, which must be explored in relation to organic matter recycling, the effects of disturbances, and the degradation of contaminants. Finally, the application of this knowledge requires the development of methods for the estimation of hydrological exchanges, especially for the management of sediment clogging, the optimization of self-purification, and the integration of climate change in environmental policies. The development of descriptors of hyporheic
\end{abstract}

\footnotetext{
*Corresponding author: pierre.marmonier@univ-lyon1.fr
} 
zone health and of new metrology is also crucial to include specific targets in water policies for the long-term management of the system and a clear evaluation of restoration strategies.

Key words: River sediment / invertebrates / microbial communities / river management

\section{Introduction}

The role of the hyporheic zone (a transitional zone located inside the river sediment where the surface water is in contact with groundwater; Fig. 1, Orghidan, 1959, 2010) has been actively documented for more than 20 years. The diversity of hyporheic fauna has been recognized through several works in a wide range of biomes around the world (e.g. Williams and Hynes, 1974; Stanford and Ward, 1988; Ward and Voelz, 1994 in North-America; Danielopol, 1989; Gibert et al., 1981; Bretschko and Leichtfried, 1988 in Europe; Cooling and Boulton, 1993; Boulton et al., 1997 in Australia and New Zealand). This zone is considered as an ecotone between surface water and groundwater inside river sediments (sensu Gibert et al., 1990) and its importance for the total river biodiversity is now well established.

More recently, several studies have been devoted to hyporheic processes. The role of this ecotone has been documented for the carbon cycle and organic matter processing (Bretschko and Leichtfried, 1987, 1988; Findlay et al., 1993; Findlay and Sobczak, 1996), for nitrogen recycling (Dahm et al., 1987; Jones and Holmes, 1996; Hinkle et al., 2001; Lefebvre et al., 2004, 2005; Birgand et al., 2007), and phosphorous river budget (Mulholland et al., 1997; Vervier et al., 2009). Recent works have highlighted the diversity of microbial communities, both for bacteria (Iribar et al., 2008; Lowell et al., 2009) and fungi (Bärlocher et al., 2008; Cornut et al., 2010). Similarly, the activities of these microbes have been studied in a wide range of rivers, from small streams (Schmid and Schmid-Araya, 2010) to large rivers (Claret et al., 1997, 1998; Fischer et al., 2005). All these studies have converged toward the idea that the hyporheic zone plays an essential role in the global metabolism of the rivers (Boulton et al., 1998, 2010; Dahm et al., 1998; Robertson and Wood, 2010; Krause et al., 2011).

Despite the significant progress made in the understanding of hyporheic zone functioning, the link between invertebrate assemblages (i.e. hyporheos), microbial communities, and ecological processes is still understudied. At the end of the "InBioProcess" program (a 4-year research program funded by the French National Research Agency, ANR2006-BIODIV-007) an international congress devoted to "the role of biodiversity in the process at groundwater - surface water interface" was organized in Lyon (January 26-28, 2011). The final discussion of this meeting highlighted several gaps in knowledge and some needs for applications, which cover five major issues. (i) The importance of physical processes for understanding the hyporheic functioning, (ii) the role of invertebrates and (iii) microbial communities in hyporheic processes, and (iv) the importance of the hyporheic zone and its biota in the global metabolism of the river. Finally (v), the needs for the application of available scientific results to inform river management, protection, and restoration must be addressed.

\section{Physical processes and hyporheic functioning (Table 1)}

Previous researches have highlighted the link between local physical constraints and hyporheic processes, for both hydrological (Hendricks and White, 1991; Hendricks, 1993) and sediment characteristics (Harvey et al., 2011) at microhabitat or reach scales (Fig. 1), but very few data are available at larger scales. Research combining flow modeling (Cardenas et al., 2004; Hester and Doyle, 2008; Peyrard et al., 2008) and field measures (Sánchez-Pérez et al., 2003a, b; Gooseff et al., 2006) is still needed to understand the relationship between sediment mobility, channel shape, and water fluxes between the river and its substratum. This is especially important for low-land sandy rivers, where hydrological exchanges are difficult to measure but are essential to maintain an oxygenated level inside hyporheic sediments (Dahm et al., 1987; Lefebvre et al., 2005). At the floodplain scale, methods are needed for a consistent measurement of spatio-temporal changes of the fluxes between the river and its related aquifer (Weng et al., 2003; Peyrard et al., 2008; Poole et al., 2008). Such measurements are needed to determine which environmental factors control these changes and how they impact river dynamics. Local measures of hyporheic physical characteristics have been performed in many studies at the reach scale (Morrice et al., 1997; Baker et al., 1999; Fellows et al., 2001), but an upscaling of these local measures to the floodplain and catchment scales is clearly needed (see Doering et al., 2006; Malard et al., 2006; Datry et al., 2007; Larned et al., 2008; Poole et al., 2008).

One of the recurrent questions in hyporheic studies is the description of the vertical changes in physical and hydrological characteristics. This is a crucial challenge in sandy and chalk streams where most of the gradients (e.g. oxygen availability, organic matter storage, and nitrogen processes) occur at the water interface and in the first $10 \mathrm{~cm}$, mainly for microbial activities. Technical advances are needed in physico-chemical sensors for long-term monitoring of hyporheic characteristics at shallow depths (e.g. Malcolm et al., 2006; Riss et al., 2008). Conventional sampling practices obscure the temporal dynamic of hyporheic processes (Kirchner et al., 2004; Greenwood et al., 2007). To describe and understand these temporal changes, we need to deploy new metrologies able to follow 
Table 1. Gaps in knowledge on the interactions between physical processes.

\begin{tabular}{lcc}
\hline General field & \multicolumn{1}{c}{ Questions to be addressed } & Needs for research \\
$\begin{array}{l}\text { Understanding the vertical } \\
\text { connectivity }\end{array}$ & $\begin{array}{c}\text { What are the links between the sediment dynamics, } \\
\text { the vertical connectivity between the river and } \\
\text { the aquifer from local to catchment scales? } \\
\text { What parameters describe best the physical } \\
\text { properties of the hyporheic zone? }\end{array}$ & $\begin{array}{c}\text { Need for documentation on hyporheic } \\
\text { processes at the "missing scale" } \\
\text { (reach and floodplain) }\end{array}$ \\
$\begin{array}{c}\text { Need for standard methods and new metrology } \\
\text { to describe the vertical gradients and temporal } \\
\text { variations of physico-chemical characteristics of } \\
\text { the interstitial water }\end{array}$ \\
$\begin{array}{l}\text { Interactions with } \\
\text { biological processes }\end{array}$ & $\begin{array}{c}\text { What are the interactions between hyporheic } \\
\text { water fluxes and biological activities? }\end{array}$ & $\begin{array}{c}\text { Methodological needs for upscaling microcosm } \\
\text { observations to reach and catchment processes }\end{array}$ \\
\hline
\end{tabular}

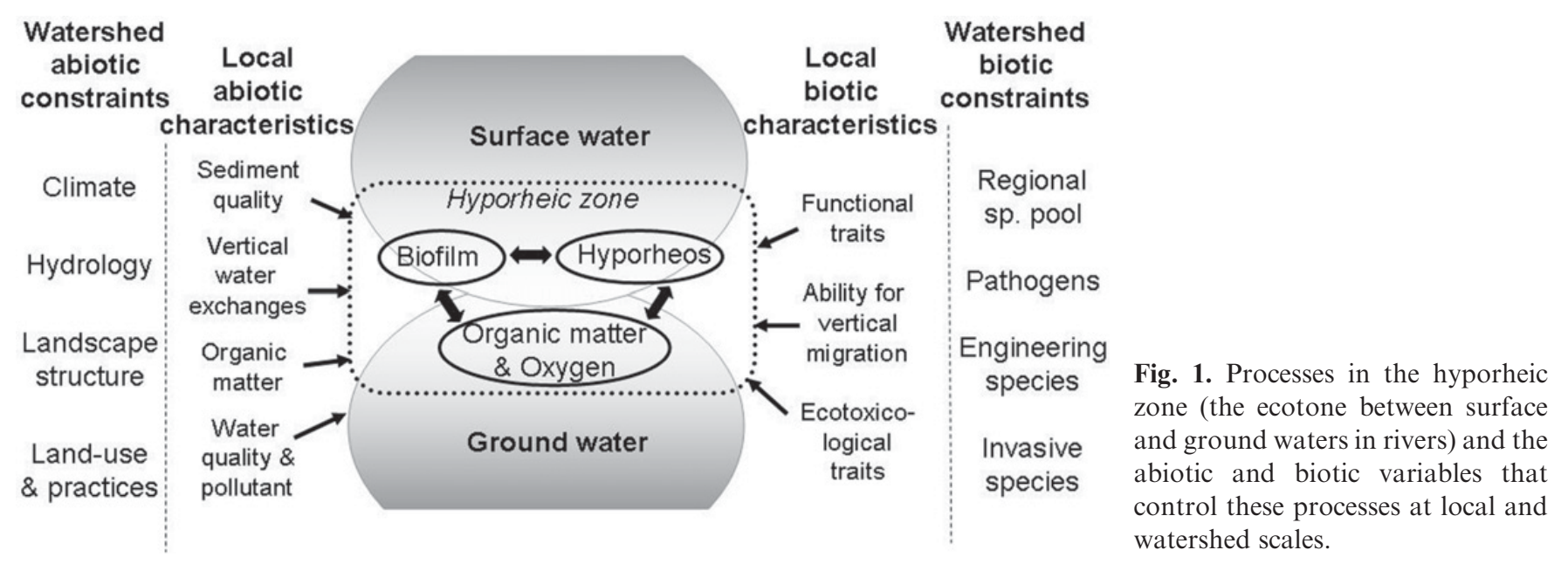

in situ and continuously the changes in environmental physico-chemical properties and which can be adapted to the spatio-temporal scales of the organisms or processes studied (Bridge, 2005). Therefore, it may be essential to develop monitoring tools such as micro-sensors to accurately quantify the physico-chemical environment of hyporheic organisms (e.g. dissolved oxygen or nitrogen forms' concentration).

The interactions between water exchanges and biological activities also need to be investigated further.

Some general models have been developed in coarse sediment temperate rivers (e.g. Hendricks, 1993) or sandybottom desert streams (Grimm and Fisher, 1984; Fisher et al., 1998) and predict the patterns of the major ecological processes in the hyporheic zone (e.g. changes in the available oxygen, respiration, nitrification, and denitrification activities along downwelling-upwelling flowpaths). Despite the existence of these models, several questions remained unsolved regarding the parameters that control hyporheic biological processes. For example, the consequences of biotic activities (biofilm clogging, invertebrate bioturbation, fish reproduction, and feeding) on the vertical exchanges of water are not completely understood. In many cases, these issues have been addressed in laboratory experiments (e.g. Mermillod-Blondin et al., 2000; Nogaro et al., 2006, 2009; Navel et al., 2010) or at the riffle-pool scale (Schmid and Schmid-Araya, 2010), but research is still required for upscaling these microcosm observations to reach, floodplain, and catchment scales.
Boulton et al. (1998) focused on the micro-habitat ( $\mu \mathrm{m}$ to $\mathrm{mm}$ ), the riffle-pool successions ( $\mathrm{m}$ to $\mathrm{dm}$ ) and the catchment scales (100-1000 km); but we know very little about intermediate scales (reach, river section, or floodplain scales, 1-10 km; Creuzé des Châtelliers and Reygrobellet, 1990; Tockner et al., 2002) where valley shape, depth of the substratum, and lateral aquifer levels seems to be determinant parameters for hyporheic hydrology (Woessner, 2000; Malard et al., 2003; Weng et al., 2003; Poole et al., 2004; Buffington and Tonina, 2009; Tonina and Buffington, 2009). The combination of large-scale studies (Claret et al., 2001) and hydrological modeling (Peyrard et al., 2008) may be an efficient strategy to understand the interactions between physical characteristics and biological processes at these multiple scales, even if processes that take place deep in the groundwater (i.e. in the phreatic zone) may hide some shallow patterns (i.e. hyporheic). For example, deep groundwater may be poor in nitrate because of long flow paths. Large-scale upwelling of such deep water may result in nitrate decrease simulating hyporheic denitrification.

\section{The dynamics of invertebrate communities (Table 2)}

Hyporheic invertebrate assemblages were one of the first biological components studied at the river-sediment interface (Orghidan, 1959). The first decade of hyporheic 
Table 2. Gaps in knowledge on hyporheic invertebrate communities.

\begin{tabular}{|c|c|c|}
\hline General field & Questions to be addressed & Needs for research \\
\hline Trophic structure & $\begin{array}{l}\text { How to determine and quantify the trophic } \\
\text { interactions within hyporheic communities? }\end{array}$ & $\begin{array}{l}\text { Need for generalization of stable isotope signature or } \\
\text { other physiological tracers for modeling energy fluxes } \\
\text { in the hyporheic communities }\end{array}$ \\
\hline Functional groups & $\begin{array}{l}\text { What are the roles of invertebrates in the } \\
\text { hyporheic zone? }\end{array}$ & Need to define functional groups in the hyporheic fauna \\
\hline Temporal changes & $\begin{array}{l}\text { How do hyporheic assemblages change with } \\
\text { seasons and what are the consequences on } \\
\text { hyporheic functions? }\end{array}$ & $\begin{array}{l}\text { Need to understand and measure vertical migration of } \\
\text { invertebrates toward the hyporheic zone during surface } \\
\text { system disturbances }\end{array}$ \\
\hline Future global changes & $\begin{array}{l}\text { What will be the effect of future global warming, } \\
\text { hyporheic hydrology, and the interaction of these } \\
\text { changes on hyporheic assemblages and } \\
\text { functions? }\end{array}$ & $\begin{array}{l}\text { Need for the evaluation of the heritage value of } \\
\text { hyporheic fauna }\end{array}$ \\
\hline
\end{tabular}

studies (1970-2000) highlighted the mix of benthic and groundwater organisms characterizing the hyporheos, its complex spatial patterns resulting from hyporheic flow paths, and its temporal variability due to hydrology (e.g. Brunke and Gonser, 1999; Fowler and Scarsbrook, 2002). However, the roles of interstitial organisms in the hyporheic processes are still poorly studied (Boulton, 2000). The first point to be clarified is how to determine and quantify the trophic interactions within hyporheic communities. Several aspects of these trophic interactions remained unknown. The carbon source of the hyporheic trophic web is difficult to elucidate. Interstitial invertebrates may feed on hyporheic biofilm that grow on mineral particles using Dissolved Organic Carbon (DOC) or on coarse Particulate Organic Matter (POM) originating from the surface (e.g. leaf detritus). Differentiating these two organic matter sources make the modeling of carbon fluxes in the hyporheic communities difficult.

This probably explains why the presence of benthic fauna, of predators, or the effect of shifts in the trophic niche of some polyphageous species is not yet understood. Nothing is known either about the presence of parasites in the hyporheic zone and its potential consequences. Suitable methods, such as stable isotope signature (Chamberlain et al., 2006; Leduc, 2009) or other physiological tracers such as fatty acids (Chamberlain et al., 2006; Leduc, 2009; Maazouzi et al., 2009), may help understand the trophic status of hyporheic species and their feeding behavior. At the moment, it seems difficult or even impossible to identify the affiliation of hyporheic species to functional groups. For example, Boulton et al. (2008) hypothesized that stygobiotic amphipods were shredders similar to their surface water relatives, but recent findings suggest that they are deposit feeders. The hypogean Niphargus rhenorhodanensis use the fecal pellets and fine detritus produced by epigean Gammarus roeselii when shredding leaf litter (Navel et al., 2011). This study also emphasizes the complex interactions that occur within the mix of benthic and hypogean organisms characterizing the hyporheos. An important numerical component of the hyporheos is the meiofauna, but our understanding of its role within the assemblage and the wider habitat is hampered by the lack of knowledge regarding species traits (but see Gaudes et al., 2010).
Compared to marine systems (e.g. Aller, 1982; Kristensen et al., 1985; Gilbert et al., 1995), information available on the roles of bioturbators in hyporheic ecological processes is very scarce. The impact of the activity of invertebrates on sediment structure has been observed in situ (Datry et al., 2003) and its influence on vertical exchanges of water has been documented through laboratory experiments (Mermillod-Blondin et al., 2003; Nogaro and Mermillod-Blondin, 2009), but few field studies have been carried out to quantify the consequences of this biological activity in contrasting natural situations (e.g. Gerino et al., 2007). Similarly, the relative ecological roles of macrofauna and meiofauna are unclear, beyond the obvious fact that large animals may modify the structure of sediment deposits and small invertebrates may have access to resources stored in very fine sandy deposits. The interaction between these organisms may explain some of the patterns observed in very heterogeneous hyporheic habitats (Hakenkamp and Morin, 2000).

Temporal changes in hyporheic assemblages have been explored in relation to natural or artificial disturbances (floods and pollution), but seasonal changes are still poorly documented. For example, the larval development of some species takes place inside river sediment (e.g. Baetis scambus, Puig et al., 1990), but nothing is known about the use by benthic invertebrates of the organic matter stored inside sediment. We need to observe the behavior of invertebrates to understand whether they actively search for the organic matter stored in the sediment, move vertically to the hyporheic zone, and modify biofilm structure and activities.

The temporal changes linked to disturbances have been widely discussed (Williams \& Hynes, 1976; Dole-Olivier et al., 1997; Wood et al., 2010), but the hyporheic refugium hypothesis is still being debated. A general framework is necessary to understand and measure the vertical migration toward the hyporheic zone during surface stream disturbances (see Robertson and Wood, 2010). It is still not clear how the structure of the food web responds to these disturbances (integrating the possible cascading effects) and consequently the nature of the interactions between benthic and hyporheic organisms, with potentially strong functional consequences. This is especially important when considering the impact of future climate 
Table 3. Gaps in knowledge on hyporheic microbial communities.

\begin{tabular}{|c|c|c|}
\hline General field & Questions to be addressed & Needs for research \\
\hline $\begin{array}{l}\text { From the laboratory } \\
\text { to the field }\end{array}$ & $\begin{array}{l}\text { Are laboratory measures relevant for assessing field } \\
\text { processes? }\end{array}$ & $\begin{array}{l}\text { Need to understand understudied microbial } \\
\text { pathways }\end{array}$ \\
\hline $\begin{array}{l}\text { Environmental } \\
\text { control }\end{array}$ & $\begin{array}{l}\text { What are the relative influences of local (grain size, } \\
\text { available resources) and regional (land-use, river } \\
\text { regulation) characteristics on microbial communities? }\end{array}$ & Need to develop large-scale field experiments \\
\hline Diversity & $\begin{array}{l}\text { What is the real degree of microbial diversity in the } \\
\text { hyporheic zone and what is the impact of this diversity } \\
\text { on major ecological processes? }\end{array}$ & $\begin{array}{l}\text { Need for a cheap and practical molecular method } \\
\text { to explore microbial diversity inside sediments }\end{array}$ \\
\hline Interactions & $\begin{array}{l}\text { What are the interactions between the different } \\
\text { microbial groups (fungi, bacteria) and the higher } \\
\text { trophic levels (invertebrates) in the hyporheic zone? }\end{array}$ & $\begin{array}{l}\text { Needs for methods to follow interactions inside } \\
\text { sediments }\end{array}$ \\
\hline $\begin{array}{l}\text { Stress and } \\
\text { disturbances }\end{array}$ & $\begin{array}{l}\text { Are the major stresses and disturbances generally } \\
\text { considered in river ecology also relevant for microbial } \\
\text { communities? }\end{array}$ & Need for descriptors of stability and resilience \\
\hline
\end{tabular}

changes and particularly of the increase in the duration and frequency of drying periods. Even methods for sampling hyporheic fauna in temporary rivers need improvements. In both cases (floods or drought), the major challenge is to know if the benthic organisms stored in the hyporheic zone can return to the benthic layer (Wood et al., 2005). In short, is the hyporheic zone a refuge or a graveyard? This problem is particularly important when considering river sediment storage as an active resilience process after disturbances.

The impact of future climate changes will not be limited to the vertical migration of benthic fauna. The consequences of warming and changes in river hydrology (and their interactions) on the hyporheic assemblages are not yet predictable. These changes will also impact the surrounding aquifers and long-term studies are needed to quantify precisely the effects of groundwater level decreases. Finally, future global change will also consist of an increase in the frequency of invasive species. This problem has been widely discussed for surface aquatic systems, both lakes (Gurevitch and Padilla, 2004; Nalepa et al., 2009) and rivers (Dukes and Mooney, 1999; Piscart et al., 2005, 2010, 2011; Werner and Rothhaupt, 2007; Strayer, 2010; Labat et al., in press). For the hyporheic zone, the occurrence of invasive species is not yet documented even if some invasive isopods and amphipods were already observed (C. Piscart, personal communication). The presence of these invaders should disturb the hyporheic communities. The subsequent question of the heritage value of the hyporheic fauna and especially its stygobiotic component (Danielopol, 2000) must be clarified for assessing and predicting future losses.

\section{Microbial communities (Table 3)}

A large number of studies that describe microbial dynamics in the sediment have been supported by potential activities measured in the laboratory, for organic matter degradation (Sinsabaugh et al., 1993; Romani et al., 2006) or nitrogen cycling (Pinay and Décamps,
1988; Clement et al., 2002; Sabater et al., 2003; Lefebvre et al., 2005). There is likely a substantial gap between these experimental activities and the intensity of the processes that take place in situ (Pinay and Décamps, 1988; SánchezPérez et al., 2003a, b; Iribar et al., 2008). This is why isotopic signature methods may help evaluate hyporheic denitrification (Sebilo et al., 2003; Lefebvre et al., 2007). To explain the dynamic of inorganic nutrients in the hyporheic zone, we also need to explore understudied microbial pathways. As highlighted in the riparian zone (Burt et al., 2010), anaerobic ammonium oxidation (Anammox, Jetten et al., 1998) is known to occur in the ocean (Engstrom et al., 2009) or in estuaries (Nicholls and Trimmer, 2009), but nothing is known for the hyporheic zone. The possible oxidation of ammonium to nitrite by ferric ions (Clement et al., 2005) must also be considered in reduced areas of fine sediment patches of the hyporheic zone.

The relationships between biofilm development and sediment grain size have been well documented (e.g. Claret et al., 1998; Battin, 2000; Romani and Sabater, 2001; Lefebvre et al., 2005; Nogaro et al., 2010), but the relative influence of local (grain size and vertical connectivity) and regional (land-use and river regulation) characteristics of hyporheic microbial communities is still poorly known. The interaction between sediment characteristics and river hydrology is also little documented for the structure and activity of the hyporheic biofilms (Navel et al., in press). One way to explore these issues may be the development of field experiments where sediment characteristics (Matthaei et al., 2006) or the local flow regime may be experimentally manipulated (Maazouzi et al., 2009).

Molecular methods for a rapid identification of microbes and diversity have been emerging for more than a decade, but very few attempts have been devoted to hyporheic microbial communities; consequently, their actual degree of diversity is still unknown (e.g. Feris et al., 2003; Griebler and Lueders, 2009). A gap exists between diversity and function. Addressing this gap is one of the most important challenges of modern ecology (e.g. Tringe et al., 2005) and new environmental genomics approaches 
Table 4. Gaps in knowledge on the role of the hyporheic zone in the global river metabolism.

\begin{tabular}{lcc}
\hline General field & \multicolumn{1}{c}{ Questions to be addressed } & Needs for research \\
\hline Upscaling & $\begin{array}{c}\text { How to upscale the processes measured in laboratory microcosms } \\
\text { or in localized stations to the reach scale? }\end{array}$ & Needs for upscaling modeling \\
$\begin{array}{c}\text { Organic matter and } \\
\text { inorganic nutrients } \\
\text { Physical disturbances }\end{array}$ & $\begin{array}{c}\text { What are the parameters controlling organic matter recycling in } \\
\text { the hyporheic zone for both organism activities and OM quality? } \\
\text { What are the effects of hydrological disturbances (e.g. floods and } \\
\text { drought) on biogeochemical processes in the hyporheic zone? }\end{array}$ & $\begin{array}{c}\text { Need to explore understudied } \\
\text { microbial pathways }\end{array}$ \\
& $\begin{array}{c}\text { Need to understand the effects of } \\
\text { changes in sediment characteristics } \\
\text { (e.g. clogging) for major } \\
\text { bollutants and toxicity }\end{array}$ & $\begin{array}{c}\text { Which parameters control contamical processes } \\
\text { zone and what consequences can be expected? }\end{array}$ \\
& & $\begin{array}{c}\text { Need for methodologies to estimate } \\
\text { the hyporheic biodegradation of } \\
\text { contaminants and its efficiency }\end{array}$ \\
\hline
\end{tabular}

may allow to link individual organisms to their displayed functions (e.g. Vandenkoornhuyse et al., 2010; Monard et al., 2011). This lack of information makes the link between microbial diversity and ecological processes (nutrient cycling or pollutant degradation) unclear. Some questions remain open, such as the role of cryptic diversity for hyporheic microbes, especially for fungi which are generally identified using spore morphology (Nikolcheva et al., 2003) or the influence of phylogeny on ecosystem functions (Battin et al., 2001). Beyond the interest of microbial diversity, the question of the interactions between the different microbial groups (fungi, archae, and bacteria) or with higher trophic levels (protozoa and invertebrates) must be addressed to understand hyporheic processes. For example, bioturbation by aquatic invertebrates is known to modify microbial activities in fine sediments (Mermillod-Blondin et al., 2005, 2008; Nogaro et al., 2007), but its consequences on microbial biofilm growing on coarse river sediment is still poorly documented and its influence on microbial diversity remains unknown. Similarly, some marine researches have demonstrated the influence of invertebrates on microbial activity and diversity via sediment reworking, grazing and bioirrigation (Aller, 1994; Gilbert et al., 1998, 2003; LópezGarcía et al., 2002), but their role in the hyporheic zone is completely unexplored.

Finally, the influence of disturbances on microbial assemblages is beginning to be understood in marine systems (Thompson et al., 2005; Atalah et al., 2007), wetlands (Ryder, 2009), and rivers (Burns and Ryder, 2001; Fischer et al., 2003), but remains understudied in the hyporheic zone. We do not know whether the major stresses and disturbances generally considered in hyporheic studies are also relevant at the microbial scale. For example, few studies are available on the effects of hydrological stress on microbial assemblages, their structure, and their activities other than denitrification (e.g. Clement et al., 2002; Kjellin et al., 2007). The predicted decrease in river discharge and increase in drought duration due to global warming may have a strong influence on the nature and intensity of hyporheic microbial activities and must be documented by field and laboratory experiments. There is thus a strong need for descriptors of the stability and resilience of hyporheic microbial assemblages.

\section{Overall metabolism (Table 4)}

Both invertebrate and microbial communities contribute to the entire metabolism of the hyporheic zone, but some questions are beyond the behavior of a single compartment and must be addressed at the ecosystem level. For example, in the hyporheic zone, the role of biodiversity is still rarely studied through group composition and food web structure approach (Sánchez-Pérez et al., 2009; Lecerf and Richardson, 2010). It is clear that the question "who is doing what in the ecosystem" matters. New environmental genomics approaches and related concepts allow addressing this key ecological question by providing the possibility of accessing at least partially every single species of a given ecosystem (Vandenkoornhuyse et al., 2010). If an environmental genomics approach is adopted, it may be possible to upscale the ecological processes measured at the local scale (station) to that of the river reach. This upscaling is a recurrent problem, despite its central position in the estimation of the relative importance of benthic and hyporheic processes at large scales (reach to catchment scales).

The determination of factors controlling organic matter recycling is another example of research that requires knowledge on a large scale. Many biological actors interact with physical constraints during leaf litter degradation (Gessner et al., 1999; Graça, 2001; Marmonier et al., 2010; Corti et al., in press; Datry et al., in press) and studies are necessary to understand the relative importance of shredding activities of invertebrate and organic matter quality in the biodegradation of leaf litter buried inside river sediment (Cornut et al., 2010; Navel et al., 2010). Similarly, nothing is known about the importance of fish spawning and feeding for the dynamics of organic matter stored inside the sediment or for the abundance and diversity of hyporheic fauna (McDermott et al., 2010). The interactions between different groups of microbes, invertebrates, and possibly fish in organic matter fluxes toward sediment must be detailed, together with the study of the potential changes in the quality of the buried organic matter. In which way do changes in organic matter quality modify the efficiency of microbial assimilation or of pollutant co-metabolism? For example, very little information is available on the biodegradation of wood 
Table 5. Needs for applications.

\begin{tabular}{|c|c|c|}
\hline General field & Questions to be addressed & Needs for research \\
\hline $\begin{array}{l}\text { Sediment and } \\
\text { hydrology }\end{array}$ & $\begin{array}{l}\text { How to localize and measure river - groundwater } \\
\text { exchanges? }\end{array}$ & Need for methods to evaluate hyporheic clogging \\
\hline Self-purification & $\begin{array}{l}\text { How to quantify the role of the hyporheic zone in } \\
\text { river self-purification? } \\
\text { How to increase the retention and biodegradation } \\
\text { of organic and mineral nutrients in the hyporheic } \\
\text { zone? }\end{array}$ & $\begin{array}{l}\text { Need for cheap and rapid field methods for retention } \\
\text { capacity measures }\end{array}$ \\
\hline Climate changes & $\begin{array}{l}\text { How to predict the effect of future climatic } \\
\text { changes (temperature and hydrology) on } \\
\text { hyporheic processes? }\end{array}$ & Need for modeling \\
\hline $\begin{array}{l}\text { Ecological } \\
\text { indicators }\end{array}$ & $\begin{array}{l}\text { What kind of indicators can be used to evaluate } \\
\text { the hyporheic zone functioning and health? }\end{array}$ & Need for indicators for early measures of changes \\
\hline Management & $\begin{array}{l}\text { How to include the hyporheic zone functions in } \\
\text { the global management of river systems? }\end{array}$ & $\begin{array}{l}\text { Need for methods to evaluate the potential of } \\
\text { hydromorphological restoration for hyporheic processes }\end{array}$ \\
\hline
\end{tabular}

within sediment (Crenshaw et al., 2002) and the role of algal exudates in hyporheic processes (Findlay et al., 1993).

The effects of hydrological disturbances (floods and drought) on biogeochemical processes in the hyporheic zone are also poorly understood (Datry and Larned, 2008; Maazouzi et al., 2009). The potential effects of discharge variation (and the resulting inputs of oxygenated surface water inside river sediment) on hyporheic respiration or denitrification must be clarified. This could be helpful to predict the effects of future climate changes (reduction in river discharge and increase in low-water period duration) or river regulation.

The movements of river sediments may strongly impact the ecological processes in the hyporheic zone as well. The changes in sediment characteristics (e.g. permeability versus clogging) modify the major biogeochemical processes through changes in the available oxygen (Claret et al., 1998; Heffernan et al., 2008) and other final electron acceptors (Nogaro and Mermillod-Blondin, 2009; Navel et al., in press). The consequences of clogging on inorganic and organic nutrient recycling must be clearly understood for an efficient management of the interface between the river and its catchment (Lefebvre et al., 2005; Nogaro et al., 2009; Descloux et al., in press).

Future research must also explore the parameters that control contaminant fluxes from the river to the hyporheic zone (xenobiotics, pesticides, trace metals, Feris et al., 2003, 2004; Williams et al., 2009) with special focus on the consequences of these inputs on the community structure, the ecological processes, and the influence of biodiversity on these fluxes (Mermillod-Blondin et al., 2003). On the one hand, there is a strong need for methodologies to estimate the hyporheic biodegradation of these pollutants (Williams et al., 2009; Landmeyer et al., 2010). A clarification of the links between local characteristics (sediment grain size, vertical connectivity, and inputs of groundwater) and the transformation rates of these pollutants is needed. Again, the effects of an increase in the lowwater period duration and the frequency of drought predicted by several climatic scenarios on the hyporheic biodegradation of pesticides must be explored. Toxicity of the pollutants stored in river sediments and the influence of vertical water exchanges must also be documented. This is especially true for the effects of sub-lethal concentrations and cocktails of contaminants on invertebrate and microbial diversity and activity. The questions about the interactions between these contaminants and nutrients remain unexplored in the hyporheic zone, despite the important role they play in the vulnerability of most rural eutrophic rivers (Piscart et al., 2009).

\section{Needs for applications (Table 5)}

The integration of the hyporheic zone in the management plans of rivers and streams is an essential challenge mentioned by several authors (Boulton, 2005; Hancock et al., 2005; Datry et al., 2007; Kasahara et al., 2009; Boulton et al., 2010), but this global objective faces several problems in applied sciences. The localization and measure of water exchange between a river and its surrounding aquifer at large scale (reach to catchment) is still problematic. At a smaller scale, the methods available to evaluate local sediment clogging are not adequate (Descloux et al., in press). The evaluation of clogging using surface quantification is highly subjective, due to high observer effect, while the methods for measuring hyporheic clogging must be improved: the hydraulic conductivity measurement (Dahm and Valett, 1996) needs calibration for an easy use by field technicians and the artificial substrate method (Marmonier et al., 2004) or survival rates of Salmonid eggs (Massa et al., 2000) cannot be used in all types of rivers. This methodological problem becomes crucial when physical (fine mineral particle deposition) and biological clogging (biofilm growth) interact in eutrophic rural streams (Lefebvre et al., 2006). The evaluation of the ecological consequences of this clogging (organic matter and nitrogen recycling, habitat availability for invertebrates and Salmonid eggs) also calls for specific methods and may increase the sensitivity of managers, especially in the EU Water Framework Directive context (European Community, 2000). The hyporheic zone is an important 
part of the river ecosystem and contributes to maintain its ecological quality (Boulton et al., 1998).

The integration of the hyporheic zone in management plans of rivers also needs to be supported by a realistic quantification of the role of the hyporheic zone in river self-purification (Fauvet et al., 2001; Lewis et al., 2007; Taleb et al., 2008; Kasahara et al., 2009; Boulton et al., 2010) compared to other retention zones (such as epilithic biofilm in gravel bed rivers; Bouletreau et al., 2006). stream sediments contribute significantly to the retention of nutrients (Krause et al., 2011), it is thus essential to develop management actions increasing the retention and the biodegradation of organic and mineral nutrients in the hyporheic zone. This is also conditioned on the availability of cheap and rapid field methods for measuring the retention capacity of the hyporheic zone or available modeling approaches to quantify the retention capacity under different hydrological and morphological conditions. Current available tracer experiments (Bencala 1993, 2000; Valett et al., 1996; Morrice et al., 1997; Baker et al., 1999) appear to many environmental managers as complex and time consuming. A fast but reliable method to evaluate sediment uptake rates may be easily accepted by river managers for the evaluation of a large range of disturbances (e.g. changes in sediment characteristics) and to integrate it into modeling approaches for river management plans.

Predictions of the potential effects of climate changes on river processes are urgently required (Carpenter et al., 1992; Meyer et al., 1999), especially for the hyporheic zone. The consequences of temperature increases on biologically mediated hyporheic processes must be clarified and offered to river managers. Some studies have highlighted a decrease in fungi diversity (Bärlocher et al., 2008), but the consequences of biofilm activities at the river scale remain unknown. Similarly, the consequences of the decrease in water discharge and increase in the drying frequency must be clarified for both the hyporheic invertebrates (Datry et al., 2007) and the microbial dynamics.

With long-term management and restoration projects being applied to an increasing number of rivers, managers need consistent and relevant ecological indicators to evaluate the hyporheic status. The taxonomic composition of the hyporheos or the dominant functional traits (e.g. Lafont et al., 2006) may represent valuable tools. In this case, the relation between pressure and impacts on the hyporheic fauna has to be clarified. Early indicators of river (and hyporheic) degradation are also needed, and they could be found in food web structure or ecological processes (respiration or substrate biodegradation rates).

Finally, the integration of the hyporheic zone in river management policies requires major progresses in the evaluation of (i) nutrient retention, (ii) microbial efficiency in pollutant biodegradation, (iii) invertebrate vertical migration, (iv) efficiency of fish reproduction, and (v) modeling approaches at the fluvial corridor scale. These advances are crucial not only for understanding and predicting the effects of management projects of the hyporheic zone at the fluvial corridor scale but also for evaluating the potential of hydro-morphological restorations of rivers. Bridging the gap between physicochemical determinants and biological processes will pave the way for physical actions and biogeochemical stimulation measures with a view to river restoration (Kasahara et al., 2009). We also need to identify specific targets in the water policies to enhance hyporheic biodiversity and river ecological dynamics in order to ensure good quality levels and acceptable socio-economical uses of water resources.

\section{Conclusion}

Fifty years after the hyporheic zone was first defined, the study of its habitat, fauna, and the related ecological processes, have made significant progress making ecotone an essential element in river functioning knowledge. Despite these advances, several questions remain unsolved and require more effort in research and application for river management. Some of these questions pertain to various components of the hyporheic zone.

First, most of us acknowledge the importance of upscaling the results obtained in laboratory experiments to the field, or from the local scale (station) to the river reach, floodplain and catchment scales. This is true for the effect of vertical connectivity between surface water and the sediment interstices for the microbial activities, their interactions with invertebrates and the resulting major ecological processes (organic matter processing or nitrogen transformation).

Second, we identified the needs in the documentation of the biological characteristics of hyporheic organisms. For example, we noticed that very little information is available on invertebrate trophic regime and hyporheic food webs, which makess assigning a functional group for most of them impossible. Similarly, the level of identification of hyporheic microbes is very low in most studies and the microbial diversity of hyporheic biofilm is more or less unexplored. Progress is particularly crucial in this field if we want to explore some understudied microbial pathways that could explain organic and mineral nutrient cycling or toxic transformation.

Third, another major problem highlighted by most of us was the effect of global changes. Hyporheic organisms will be particularly impacted by future climatic changes because of the combination of temperature rising and changes in river and groundwater hydrology. The origin of water (downwelling versus upwelling, loosing versus gaining) is crucial for most hyporheic organisms, and its modification will certainly induce unpredicted consequences on hyporheic functioning. Global warming will certainly have significant effects on hyporheic invertebrate life cycle (for both timing and duration), but changes in groundwater inputs will modify assemblage composition and salmonid egg survival and development (Ojanguren and Braña, 2003). Moreover, changes in the composition and activity of microbial communities will modify hyporheic biofilm functions and the intensity of some recycling 
processes will deeply change. Finally, global change will induce modifications in the frequency and intensity of hydrological disturbances (low water periods, droughts or extreme summer spates), which will modify vertical water exchanges and sediment mobility and consequently, microbial and invertebrate community composition and diversity. To face these future challenges, it is essential to answer at least some of the questions addressed here.

Acknowledgements. We thank the "InBioProcess" program of the National Research Agency (ANR-2006-BDIV-007), VeoliaEau, Envirhonalp, the CNRS (Institut Ecologie Environnement - INEE), the University of Lyon 1, and the Paul Cézanne University (Aix-Marseille 3) for supporting the 26-28 January congress "the role of biodiversity in the process at groundwatersurface water interface" (Villeurbanne, France). We thank the Rhone Catchment Long-Term Ecological Research Area (ZABR), the Field Observatory for Urban Water Management (OTHU), and the RM\&C Water Agency.

\section{References}

Aller R.C., 1982. The effects of macrobenthos on chemical properties of marine sediment and overlying water. In: McCall, P.L. and Tevesz, M.J.S. (eds.), Animal Sediment Relations. The Biogenic Alteration of Sediments, Plenum Publishing Corporation, New York, 53-102.

Aller R.C., 1994. Bioturbation and remineralization of sedimentary organic matter: effects of redox oscillation. Chem. Geol., $114,331-345$.

Atalah J., Otto S.A., Anderson M.J., Costello M.J., Lenz M. and Wahl M., 2007. Temporal variance of disturbance did not affect diversity and structure of a marine fouling community in north-eastern. New Zealand. Mar. Biol., 153, 199-211.

Baker M.A., Dahm C.N. and Valett H.M., 1999. Acetate retention and metabolism in the hyporheic zone of a mountain stream. Limnol. Oceanogr., 44, 1530-1539.

Bärlocher F., Seena S., Wilson K.P. and Williams D.D., 2008. Raised water temperature lowers diversity of hyporheic aquatic hyphomycetes. Freshwater Biol., 53, 368-379.

Battin T.J., 2000. Hydrodynamics is a major determinant of streambed biofilm activity: From the sediment to the reach scale. Limnol. Oceanogr., 45, 1308-1319.

Battin T.J., Wille A., Sattler B. and Psenner R., 2001. Phylogenetic and functional heterogeneity of sediment biofilms along environmental gradients in a glacial stream. Appl. Environ. Microbiol., 67, 799-807.

Bencala K.E., 1993. A perspective on stream-catchment connections. J. N. Am. Benthol. Soc., 12, 44-47.

Bencala K.E., 2000. Hyporheic zone hydrological processes. Hydrol. Process., 14, 2797-2798.

Birgand F., Skaggs R.W., Chescheir G.M. and Gilliam J.W., 2007. Nitrogen removal in streams of agricultural catchments - a literature review. Crit. Rev. Environ. Sci. Technol., 37, 381-487.

Bouletreau S., Garabetian F., Sauvage S. and Sánchez-Pérez J.M., 2006. Assessing the importance of self-generated detachment process in river biofilm models. Freshwater Biol., 51, 901-912.
Boulton A.J., 2000. The functional role of the hyporheos. Verh. Int. Ver. Theor. Angew. Limnol., 27, 51-63.

Boulton A.J., 2005. Chances and challenges in the conservation of groundwater-dependent ecosystems. Aquat. Conserv.: Mar. Freshwater Ecosyst., 15, 319-323.

Boulton A.J., Scarsbrook M.R., Quinn J.M. and Burrell G.P., 1997. Land-use effects on the hyporheic ecology of five small streams near Hamilton, New Zealand. N. Z. J. Mar. Freshwater Res., 31, 609-622.

Boulton A.J., Findlay S., Marmonier P., Stanley E.H. and Valett H.M., 1998. The functional significance of the hyporheic zone in streams and rivers. Annu. Rev. Ecol. Syst., 29, 59-81.

Boulton A.J., Fenwick G.D., Hancock P.J. and Harvey M.S., 2008. Biodiversity, functional roles and ecosystem services of groundwater invertebrates. Invertebr. Syst., 22, 103-116.

Boulton A.J., Datry T., Kasahara T., Mutz M. and Stanford J.A., 2010. Ecology and management of the hyporheic zone: stream-groundwater interactions of running waters and their floodplains. J. N. Am. Benthol. Soc., 29, 26-40.

Bretschko G. and Leichtfried M., 1987. The determination of organic matter in river sediments. Arch. Hydrobiol. Suppl., 68, 403-417.

Bretschko G. and Leichtfried M., 1988. Distribution of organic matter and fauna in a second order alpine gravel stream (RITRODAT-Lunz). Verh. Int. Verein. Limnol., 23, 13331339.

Bridge J., 2005. High resolution in-situ monitoring of hyporheic zone biogeochemistry, Science Report SC030155/SR3, Environment Agency, Bristol, 51 p.

Brunke M. and Gonser T., 1999. Hyporheic invertebrates - the clinal nature of interstitial communities structured by hydrological exchange and environmental gradients. J. N. Am. Benthol. Soc., 18, 344-362.

Buffington J.M. and Tonina D., 2009. Hyporheic exchange in mountain rivers II: effects of channel morphology on mechanics, scales, and rates of exchange. Geogr. Compass, 3, 1038-1062.

Burns A. and Ryder D.S., 2001. Potential for biofilms as biological indicators in Australian riverine systems. Ecol. Manage. Rest., 2, 53-63.

Burt T., Pinay G. and Sabater S., 2010. What do we still need to know about the ecohydrology of riparian zones? Ecohydrology, 3, 373-377.

Cardenas M.B., Wilson J.L. and Zlotnik V.A., 2004. Impact of heterogeneity, bed forms, and stream curvature on subchannel hyporheic exchange. Water Resour. Res., 40, W08307.

Carpenter S.R., Fisher S.G., Grimm N.B. and Kitchell J.F., 1992. Global change and freshwater ecosystems. Annu. Rev. Ecol. Syst., 23, 119-139.

Chamberlain P.M., Bull I.D., Black H.I.J., Ineson P. and Evershed R.P., 2006. Collembolan trophic preferences determined using fatty acid distributions and compoundspecific stable carbon isotope values. Soil Biol. Biochem., 38, 1275-1281.

Claret C., Marmonier P., Boissier J.M., Fontvieille D. and Blanc P., 1997. Nutrient transfer between parafluvial interstitial water and river water: influence of gravel bar heterogeneity. Freshwater Biol., 37, 657-670.

Claret C., Marmonier P. and Bravard J.P., 1998. Seasonal dynamics of nutrient and biofilm in interstitial habitats of 
two contrasting riffles in a regulated large river. Aquat. Sci., $60,33-55$.

Claret C., Boulton A.J., Dole-Olivier M.J. and Marmonier P., 2001. Functional processes versus state variables: interstitial organic matter pathways in floodplain habitats. Can. J. Fish. Aquat. Sci., 58, 1594-1602.

Clement J.C., Pinay G. and Marmonier P., 2002. Seasonal dynamics of denitrification along topohydrosequences in three different riparian wetlands. J. Environ. Qual., 31, 1025-1037.

Clement J.C., Shrestha J., Ehrenfeld J.G. and Jaffe P.R., 2005. Ammonium oxidation coupled to dissimilatory reduction of iron under anaerobic conditions in wetland soils. Soil Biol. Biochem., 37, 2323-2328.

Cooling M.P. and Boulton A.J., 1993. Aspects of the hyporheic zone below the terminus of a South Australian arid-zone stream. Aust. J. Mar. Freshwater Res., 44, 411-426.

Cornut J., Elger A., Lambrigot D., Marmonier P. and Chauvet E., 2010. Early stages of leaf decomposition are mediated by aquatic fungi in the hyporheic zone of woodland streams. Freshwater Biol., 55, 2541-2556.

Corti R., Datry T., Drummond L. and Learned S., 2011. Natural variation in immersion and emersion affects breakdown and invertebrate colonization of leaf litter in temporary river. Aquat. Sci., 73, 537-550.

Crenshaw C.L., Valett H.M. and Tank J.L., 2002. Effects of coarse particulate organic matter on fungal biomass and invertebrate density in the subsurface of a head- water stream. J. N. Am. Benthol. Soc., 21, 28-42.

Creuzé des Châtelliers M. and Reygrobellet J.L., 1990. Interactions between geomorphological processes, benthic and hyporheic communities: first results on a bypassed canal of the French upper Rhône river. Regul. Riv., 5, $139-158$.

Dahm C.N. and Valett H.M., 1996. Hyporheic zones. In: Methods in Stream Ecology, A. H. F. R. a. L. G., Academic Press, San Diego, California, 53-74.

Dahm C.N., Trotter E.H. and Sedell J.R., 1987. Role of anaerobic zones and processes in stream ecosystem productivity. In: Averett R.C. and McKnight D.M. (eds.), Chemical Quality of Water and the Hydrologic Cycle, Lewis Publishers, Chelsea, 157-178.

Dahm C.N., Grimm N.B., Marmonier P., Valett H.M. and Vervier P., 1998. Nutrient Dynamics at the interface between surface waters and ground waters. Freshwater Biol., 40, 427-451.

Danielopol D.L., 1989. Groundwater fauna associated to riverine aquifers. J. N. Am. Benthol. Soc., 8, 18-35.

Danielopol D.L., 2000. Biodiversity in groundwater: a largescale view. Trends Ecol. Evol., 15, 223-224.

Datry T. and Larned S.T., 2008. River flow controls ecological processes and invertebrate assemblages in subsurface flowpaths of an ephemeral river reach. Can. J. Fish. Aquat. Sci., $65,1532-1544$.

Datry T., Corti R., Claret C. and Philippe M., 2011. Flow intermittence controls leaf litter breakdown in a French temporary alluvial river: the "drying memory". Aquat. Sci., 73, 471-483.

Datry T., Malard F., Niedereitter R. and Gibert J., 2003. Video logging for examining biogenic structures in deep heterogeneous subsurface sediments. C. R. Acad. Sci. Biol., $326,589-597$.
Datry T., Larned S.T. and Scarsbrook M.R., 2007. Responses of hyporheic invertebrate assemblages to large-scale variation in flow permanence and surface-subsurface exchange. Freshwater Biol., 52, 1452-1462.

Descloux S., Datry T., Philippe M. and Marmonier P., 2010. Comparison of different techniques to assess surface and subsurface streambed colmation with fine sediments. Int. Rev. Hydrobiol, 95, 520-540.

Doering M., Uehlinger U., Rotach A., Schläpfer D. and Tockner K., 2006. Large-scale expansion and contraction dynamics along an unconstrained alpine alluvial corridor (Tagliamento River, Northeast Italy). Earth Surf. Process. Landforms, 32, 1693-1704.

Dole-Olivier M.J., Marmonier P. and Beffy J.L., 1997. Response of invertebrates to lotic disturbance: is the hyporheic zone a patchy refugium?Freshwat. Biol., 37, 257-276.

Dukes J.S. and Mooney H.A., 1999. Does global change increase the success of biological invaders?Trends Ecol. Evol., 14, 135-139.

Engstrom P., Penton C.R. and Devol A.H., 2009. Anaerobic ammonium oxidation in deep-sea sediments off the Washington margin. Limnol. Oceanogr., 54, 1643-1652.

European Community, 2000. Directive 2000/60/EC of the European Parliament and of the Council establishing a framework for the Community action in the field of water policy.

Fauvet G., Claret C. and Marmonier P., 2001. Influence of benthic and interstitial processes on nutrient changes along a regulated reach of a large river (Rhône River, France). Hydrobiologia, 445, 121-131.

Fellows C.S., Valett H.M. and Dahm C.N., 2001. Whole-stream metabolism in two montane streams: Contribution of the hyporheic zone. Limnol. Oceanogr., 46, 523-531.

Feris K.P., Ramsey P.W., Frazar C., Rillig M.C., Gannon J.E. and Holben W.E., 2003. Structure and seasonal dynamics of hyporheic zone microbial communities in free-stone Rivers of the western United States. Microb. Ecol., 46, 200-215.

Feris K.P., Ramsey P.W., Frazar C., Rillig M.C., Moore J.N., Gannon J.E. and Holben W.E., 2004. Seasonal dynamics of shallow-hyporheic-zone microbial community structure along a heavy-metal contamination gradient. Appl. Environ. Microbiol., 70, 2323-2331.

Findlay S. and Sobczak W.V., 1996. Variability in removal of dissolved organic carbon in hyporheic sediments. J. N. Am. Benthol. Soc., 15, 35-41.

Findlay S., Strayer D., Goumbala C. and Gould K., 1993. Metabolism of streamwater dissolved organic carbon in the shallow hyporheic zone. Limnol. Oceanogr., 38, 1493-1499.

Fisher S.G., Grimm N.B., Marti E., Holmes R.M. and Jones J.B., 1998. Material spiraling in stream corridors: a telescoping ecosystem model. Ecosystems, 1, 19-34.

Fischer H., Sukhodolov A., Wilczek S. and Engelhardt C., 2003. Effects of flow dynamics and sediment movement on microbial activity in a lowland river. River Res. Appl., 19, 473-482.

Fischer H., Kloep F., Wilzcek S. and Pusch M.T., 2005. A river's liver - microbial processes within the hyporheic zone of a large lowland river. Biogeochemistry, 76, 349-371.

Fowler R.T. and Scarsbrook M.R., 2002. Influence of hydrologic exchange patterns on water chemistry and hyporheic invertebrate communities in three gravel-bed rivers. $N$. Z. J. Mar. Freshwater Res., 36, 471-482. 
Gaudes A., Artigas J. and Munoz I., 2010. Species traits and resilience of floods and drought in a Mediterranean stream. Mar. Freshwater Res., 61, 1336-1347.

Gerino M., Frignani M., Mugnai C., Bellucci L.G., Prevedelli D., Valentini A., Castelli A., Delmotte S. and Sauvage S., 2007. Bioturbation in the Venice lagoon: rates and relationship to organisms. Acta Oecol., 32, 14-25.

Gessner M.O., Chauvet E. and Dobson M., 1999. A perspective on leaf litter breakdown in streams. Oikos, 85, 377-384.

Gibert J., Ginet R., Mathieu J. and Reygrobellet J.L., 1981. Structure et fonctionnement des écosystèmes du Haut-Rhône français. IX - Analyse des peuplements de deux stations phréatiques alimentant des bras morts. Int. J. Speleol., 11, 141-158.

Gibert J., Dole-Olivier M.J., Marmonier P. and Vervier P. 1990. Surface water-Groundwater ecotones. In: Naiman R.J. and Décamps H. (eds.), Ecology and Management of AquaticTerrestrial Ecotones, Partenon Publications, London, 199-225.

Gilbert F., Bonin P. and Stora G., 1995. Effect of bioturbation on denitrification in a marine sediment from the West Mediterranean littoral. Hydrobiologia, 304, 49-58.

Gilbert F., Stora G. and Bonin P., 1998. Influence of bioturbation on denitrification activity in Mediterranean coastal sediments: an in situ experimental approach. Mar. Ecol. Prog. Ser., 163, 99-107.

Gilbert F., Hulth S. and Aller R.C., 2003. The influence of macrofaunal burrow spacing and diffusive scaling on sedimentary nitrification and denitrification: an experimental and model approach. J. Mar. Res., 61, 101-125.

Gooseff M.N., Anderson J.K., Wondzell S.M., LaNier J. and Haggerty R., 2006. A modelling study of hyporheic exchange pattern and the sequence size, and spacing of stream bedforms in mountain stream networks, Oregon, USA. Hydrol. Proc., 20, 2443-2457.

Graça M.A., 2001. The Role of Invertebrates on Leaf Litter Decomposition in Streams - a Review. Int. Rev. Hydrobiol., 86, 383-393.

Greenwood R., Mills G.A. and Roig B., 2007. Introduction to emerging tools and their use in water monitoring. Trends Anal. Chem., 26, 263-267.

Griebler C. and Lueders T., 2009. Towards a conceptual understanding of microbial biodiversity in groundwater ecosystems. Freshwater Biol., 54, 649-677.

Grimm N.B. and Fisher S.G., 1984. Exchange between interstitial and surface water: implications for stream metabolism and nutrient cycling. Hydrobiologia, 111, 219-228.

Gurevitch J. and Padilla D.K., 2004. Are invasions a major cause of extinctions? Trends Ecol. Evol., 19, 470-474.

Hakenkamp C. and Morin A., 2000. The importance of meiofauna to lotic ecosystem functioning. Freshwater Biol., 44, 165-175.

Hancock P.J., Boulton A.J. and Humphreys W.F., 2005. Aquifers and hyporheic zones: Towards an ecological understanding of groundwater. Hydrogeol. J., 13, 98-111.

Harvey B.N., Johnson M.L., Kiernan J.D. and Green P.G., 2011. Net dissolved inorganic nitrogen production in hyporheic mesocosms with contrasting sediment size distributions. Hydrobiologia, 658, 343-352.

Heffernan J.B., Sponseller R.A. and Fisher S.G., 2008. Consequences of a biogeomorphic regime shift for the hyporheic zone of a Sonoran Desert stream. Freshwater Biol., 53, 1954-1968.

Hendricks S.P., 1993. Microbial ecology of the hyporheic zone: a perspective integrating hydrology and biology. J. N. Am. Benthol. Soc., 12, 70-78.

Hendricks S.P. and White D.S., 1991. Physicochemical patterns within a hyporheic zone of a Northen Michigan River, with comments on surface water patterns. Can. J. Fish. Aquat. Sci., 48, 1645-1654.

Hester E.T. and Doyle M.W., 2008. In-stream geomorphic structures as drivers of hyporheic exchange. Water Resour. Res., 44, W03417.

Hinkle S.R., Duff J.H., Triska F.J., Laenen A., Gates E.B., Bencala K.E., Wentz D.A. and Silva S.R., 2001. Linking hyporheic flow and nitrogen cycling near the Willametter River - a large river in Oregon, USA. J. Hydrol., 244, 157-180.

Iribar A., Sánchez-Pérez J.M., Lyautey E. and Garabétian F., 2008. Differentiated free-living and sediment-attached bacterial community structure inside and outside denitrification hotspots in the river-groundwater interface. Hydrobiologia, 598, 109-121.

Jetten M.S.M., Strous M., Van der Pas-Schoonen K.T., Schalk J., Van Dongen U.G.J.M., Van der Graaf A.A., Logemann S., Muyzer G., Van Loosdrecht M.C.M. and Kuenen J.G., 1998. The anaerobic oxidation of ammonium. FEMS Microbiol. Rev., 22, S.421-437.

Jones J.B. and Holmes R.M., 1996. Surface-subsurface interactions in stream ecosystems. Trends Ecol. Evol., 11, 239-242.

Kasahara T., Datry T., Mutz M. and Boulton A., 2009. Restoration of stream-groundwater linkages in streams and rivers. Mar. Freshwater Res., 60, 976-981.

Kirchner J.W., Feng X.H., Neal C. and Robson A.J., 2004. The fine structure of water-quality dynamics: the (high-frequency) wave of the future. Hydrol. Process., 18, 1353-1359.

Kjellin J., Hallin S. and Worman A., 2007. Spatial variations in denitrification activity in wetland sediments explained by hydrology and denitrifying community structure. Water Res., 41, 4710-4720.

Krause S., Hannah D.M., Fleckenstein J.H., Heppell C.M., Picku R., Pinay G., Robertson A.L. and Wood P.J., 2011. Inter-disciplinary perspectives on processes in the hyporheic zone. Ecohydrology, 4, 481-499.

Kristensen E., Jensen M.H. and Andersen T.K., 1985. The impact of polychaete (Nereis virens Sars) burrows on nitrification and nitrate reduction in estuarine sediments. J. Exp. Mar. Biol. Ecol., 85, 75-91.

Labat F., Piscart C., Fontan B., 2011. First records, pathways and distributions of four new Ponto-Caspian amphipods in France. Limnologica, 41, 290-295.

Lafont M., Vivier A., Nogueira S., Namour P. and Breil P., 2006. Surface and hyporheic oligochaete assemblages in a French suburban stream. Hydrobiologia, 564, 183193.

Landmeyer J.E., Bradley P.M., Trego D.A., Hale K.G. and Haas J.E., 2010. MTBE, TBA, and TAME Attenuation in Diverse Hyporheic Zones. Ground Water, 48, 30-41.

Larned S.T., Hicks M.D., Schmidt J., Davey A.J.H., Dey K., Scarsbrook M., Arscott D.B. and Woods R.A., 2008. The Selwyn River of New Zealand: a benchmark system for alluvial plain rivers. River Res. Appl., 24, 1-21. 
Lecerf A. and Richardson J.S., 2010. Biodiversity-ecosystem function research: Insights gained from streams. River Res. Appl., 26, 45-54.

Leduc D., 2009. Description of Oncholaimus moanae sp. nov. (Nematoda: Oncholaimidae), with notes on feeding ecology based on isotopic and fatty acid composition. J. Mar. Biol. Assoc. UK, 89, 337-344.

Lefebvre S., Marmonier P. and Pinay G., 2004. Stream regulation and Nitrogen dynamics in sediment interstices: comparison of natural and straightened sectors of a thirdorder stream. River Res. Appl., 20, 499-512.

Lefebvre S., Marmonier P. and Peiry J.L., 2006. Nitrogen dynamics in rural streams: differences between geomorphologic units. Int. J. Limnol., 42, 43-52.

Lefebvre S., Clement J.C., Pinay G., Thenail C., Durand P. and Marmonier P., 2007. 15N-Nitrate signature in streams: effects of land-cover and agriculture practices. Ecol. Appl., 17, 2333-2346.

Lefebvre S., Marmonier P., Pinay G., Bour O., Aquilina L. and Baudry J., 2005. Nutrient dynamics in interstitial habitats of low-order rural streams with different bedrock geology. Arch. Hydrobiol., 164, 169-191.

Lewis D.B., Grimm N.B., Harms T.K. and Schade J.D., 2007. Subsystems, flowpaths, and the spatial variability of nitrogen in fluvial ecosystem. Landscape Ecol., 22, 911-924.

Lopez-Garcia P., Gaill F. and Moreira D., 2002. Wide bacterial diversity associated with tubes of the vent worm Riftia pachyptila. Environ. Microbiol., 4, 204-215.

Lowell J.L., Gordon N., Engstrom D., Stanford J.A., Holben W.E. and Gannon J.E., 2009. Habitat heterogeneity and associated microbial community structure in a smallscale floodplain hyporheic flow path. Microb. Ecol., 58, 611-620.

Maazouzi C., Piscart C., Pihan J.C. and Masson G., 2009. Effect of habitat-related resources on fatty acid composition and body weight of the invasive Dikerogammarus villosus in an artificial reservoir. Fundam. Appl. Limnol., 175, 327-338.

Malard F., Gallassi D., Lafont M., Dolédec S. and Ward J.V., 2003. Longitudinal patterns of invertebrates in the hyporheic zone of a glacial river. Freshwater Biol., 48, 1709-1725.

Malard F., Uehlinger U., Zah R. and Tockner K., 2006. Floodpulse and riverscape dynamics in a braided glacial river. Ecology, 87, 704-716.

Malcolm I.A., Soulsby C. and Youngson A.F., 2006. High frequency logging technologies reveal state dependant hyporheic process dynamics: implications for hydroecological studies. Hydrol. Process., 20, 615-622.

Marmonier P., Delettre Y., Lefebvre S., Guyon J. and Boulton A.J., 2004. A simple technique using wooden stakes to estimate vertical patterns of interstitial oxygenation in the beds of rivers. Arch. Hydrobiol., 160, 133-143.

Marmonier P., Piscart C., Sarriquet P.E., Azam D. and Chauvet E., 2010. Relevance of large litter bag burial for the study of leaf breakdown in the hyporheic zone. Hydrobiologia, 641, 203-214.

Massa F., Baglinière J.L., Prunet P. and Grimaldi C., 2000. Survie embryo-larvaire de la truite (Salmo trutta) et conditions chimiques dans la frayère. Cybium, 24 (Suppl.), 129-140.

Matthaei C.D., Weller F., Kelly D.W. and Townsend C.R., 2006. Impacts of fine sediment addition to tussock, pasture, dairy and deer farming streams in New Zealand. Freshwater Biol., 51, 2154-2172.

McDermott M.J., Robertson A.L., Shaw P.J. and Milner A.M., 2010. The hyporheic assemblage of a recently formed stream following deglaciation in Glacier Bay, Alaska. Can. J. Fish. Aquat. Sci., 67, 304-313.

Mermillod-Blondin F., Creuzé des Châtelliers M., Gerino M. and Gaudet J.P., 2000. Testing the effect of Limnodrilus sp. (Oligochaeta, Tubificidae) on organic matter and nutrient processing in the hyporheic zone: a microcosm method. Arch. Hydrobiol., 149, 467-487.

Mermillod-Blondin F., Gaudet J.P., Gerino M. and Creuzé des Châtelliers M., 2003. Influence of macroinvertebrates on physico-chemical and microbial processes in the hyporheic sediments. Hydrol. Process., 17, 779-794.

Mermillod-Blondin F., Nogaro G., Datry T., Malard F. and Gibert J., 2005. Do tubificid worms influence the fate of organic matter and pollutants in stormwater sediments? Environ. Pollut., 134, 57-69.

Mermillod-Blondin F., Nogaro G., Vallier F. and Gibert J., 2008. Laboratory study highlights the key influences of stormwater sediment thickness and bioturbation by tubificid worms on dynamics of nutrients and pollutants in stormwater retention systems. Chemosphere, 72, 213-223.

Meyer J.L., Sale M.J., Mulholland P.J. and LeRoy Poff N., 1999. Impacts of climate change on aquatic ecosystem functioning and health. J. Am. Water Res. Assoc., 35, 1373-1386.

Monard C., Vandenkoornhuyse P., Le Bot B., Binet F., 2011. Relationship between bacterial diversity and function under biotic control: the soil pesticide degraders as a case study. ISME J., 5, 1048-1056.

Morrice J.A., Valett H.M., Dahm C.N. and Campana M.E., 1997. Alluvial characteristics, groundwater-surface water exchange and hydrologic retention in headwater streams. Hydrol. Process., 11, 253-267.

Mulholland P.J., Marzolf E.R., Webster J.R., Hart D.R. and Hendricks S.P., 1997. Evidence of hyporheic retention of phosphorus in Walker Branch. Limnol. Oceanogr., 42, 443-451.

Nalepa T.F., Fanslow D.L. and Lang G.A., 2009. Transformation of the offshore benthic community in Lake Michigan: recent shift from the native amphipod Diporeia spp. to the invasive mussel Dreissena rostriformis bugenis. Freshwater Biol., 54, 466-479.

Navel S., Mermillod-Blondin F., Montuelle B., Chauvet E., Simon L., Piscart C. and Marmonier P., 2010. Interactions between fauna and sediment characteristics control plant matter breakdown in river sediments. Freshwater Biol., 55, 753-766.

Navel S., Simon L., Lecuyer C., Fourel F. and MermillodBlondin F., 2011. The shredding activity of gammarids facilitates the processing of organic matter by the subterranean amphipod Niphargus rhenorhodanensis. Freshwater Biol., 56, 481-49.

Navel S., Mermillod-Blondin F., Montuelle B., Chauvet E., Simon L. and Marmonier P., 2011. Water-sediment exchanges control microbial processes associated with leaf litter degradation in the hyporheic zone: a microcosm study., 61, 968-79.

Nicholls J.C. and Trimmer M., 2009. Widespread occurrence of the anammox reaction in estuarine sediments. Aquat. Microbiol. Ecol., 55, 105-113. 
Nikolcheva L.G., Cockshutt A.M. and Barlocher F., 2003. Determining diversity of freshwater fungi on decaying leaves: Comparison of traditional and molecular approaches. Appl. Environ. Microbiol., 69, 2548-2554.

Nogaro G. and Mermillod-Blondin F., 2009. Stormwater sediment and bioturbation influences on hydraulic functioning, biogeochemical processes, and pollutant dynamics in laboratory infiltration systems. Environ. Sci. Technol., 43, 3632-3638.

Nogaro G., Mermillod-Blondin F., François-Carcaillet F., Gaudet J.P., Lafont M. and Gibert J., 2006. Invertebrate bioturbation can reduce the clogging of sediment: an experimental study using filtration sediment columns. Freshwater Biol., 51, 1458-1473.

Nogaro G., Mermillod-Blondin F., Montuelle B., Boisson J.C., Lafont M., Volat B. and Gibert J., 2007. Do tubificid worms influence organic matter processing and fate of pollutants in stormwater sediments deposited at the surface of infiltration systems? Chemosphere, 70, 315-328.

Nogaro G., Mermillod-Blondin F., Valett H.M., FrançoisCarcaillet F., Gaudet J.P., Lafont M. and Gibert J., 2009. Ecosystem engineering at the sediment-water interface: bioturbation and consumer-substrate interaction. Oecologia, 161, 125-138.

Nogaro G., Datry T., Mermillod-Blondin F. and Montuelle B., 2010. Influence of streambed sediment clogging on microbial processes in the hyporheic zone. Freshwater Biol., 55, $1288-1302$.

Ojanguren A.F. and Braña F., 2003. Thermal dependence of embryonic growth and development in brown trout. J. Fish Biol., 62, 580-590.

Orghidan T., 1959. Ein neuer Lebensraum des unterirdischen Wassers: Der hyporheische Biotop. Arch. Hydrobiol., 55, 392-414.

Orghidan T., 2010. A new habitat of subsurface waters: the hyporheic biotope. Fundam. Appl. Limnol., 176, 291-302.

Peyrard D., Sauvage S., Vervier P., Sánchez-Pérez J.M. and Quintard M., 2008. A coupled vertically integrated model to describe lateral exchanges between surface and subsurface in large alluvial floodplains with a fully penetrating river. Hydrol. Process., 22, 4257-4273.

Pinay G. and Décamps H., 1988. The role of riparian woods in regulating nitrogen fluxes between the alluvial aquifer and surface water: a conceptual model. Regul. Riv., 2, 507-516.

Piscart C., Moreteau J.C. and Beisel J.N., 2005. Biodiversity and structure of macroinvertebrate communities along a small permanent salinity gradient (Meurthe River, France). Hydrobiologia, 551, 227-236.

Piscart C., Genoel R., Dolédec S., Chauvet E. and Marmonier P., 2009. Effects of intense agricultural practices on heterotrophic processes in streams. Environ. Pollut., 157, 10111018.

Piscart C., Bergerot B., Lafaille P. and Marmonier P., 2010. Are amphipod invaders a threat to regional biodiversity? Biol. Invasions, 12, 853-863.

Piscart C., Roussel J.M., Dick J.T.A., Grosbois G. and Marmonier P., 2011. Effects of coexistence on the habitat use and trophic ecology of interacting native and invasive amphipods. Freshwater Biol., 56, 325-334.

Poole G.C., Stanford J.A., Running S.W., Frissell C.A., Woessner W.W. and Ellis B.K., 2004. A patch hierarchy approach to modeling surface and subsurface hydrology in complex flood-plain environments. Earth Surf. Process. Landforces, 29, 1259-1274.

Poole G.C., O'Daniel S.J., Jones K.L., Woessner W.W., Bernhardt E.S., Helton A.M., Stanford J.A., Boer B.R. and Beechie T.J., 2008. Hydrologic spiralling: the role of multiple interactive flow paths in stream ecosystems. River Res. Appl., 24, 1018-1031.

Puig M.A., Sabater F. and Malo J., 1990. Benthic and hyporheic faunas of mayflies and stoneflies in the Ter River Basin (NESpain). In: Campbell I.C. (ed.), Mayflies and Stoneflies: Life Histories and Biology, Kluwer Academic Publishers, Dordrecht, 255-258.

Riss H.W., Meyer E.I. and Niepagenkemper O., 2008. A novel and robust device for repeated small-scale oxygen measurement in riverine sediments implications for advanced environmental surveys. Limnol. Oceanogr. Met., 6, 200-207.

Robertson A.L. and Wood P.J., 2010. Ecology of the hyporheic zone: origins, current knowledge and future directions. Fundam. Appl. Limnol., 176, 279-289.

Romani A.M. and Sabater S., 2001. Structure and activity of rock and sand biofilms in a Mediterranean stream. Ecology, $82,3232-3245$

Romani A.M., Fischer H., Mille-Lindblom C. and Tranvik L.J., 2006. Interactions of bacteria and fungi on decomposing litter: Differential extracellular enzyme activities. Ecology, 87, 2559-2569.

Ryder D.S., 2009. Responses of epixylic biofilm metabolism to water level variability in a regulated floodplain river. $J . N$. Am. J. Benthol. Soc., 23, 214-223.

Sabater S., Butturini A., Clement J.C., Burt T., Dowrick D., Hesfting M., Maitre V., Pinay G., Postolache C., Rzepecki M. and Sabater F.N., 2003. Nitrogen removal by riparian buffers under various $\mathrm{N}$ loads along a European climatic gradient: patterns and factors of variation. Ecosystems, 6, 20-30.

Sánchez-Pérez J.M., Bouey C., Sauvage S., Teissier S., Antigüedad I. and Vervier P., 2003a. A standardized method for measuring in situ denitrification in shallow aquifers: numerical validation and measurements in riparian wetlands. Hydrol. Earth Sci. Syst., 7, 87-96.

Sánchez-Pérez J.M., Vervier P., Garabétian F., Sauvage S., Loubet M., Rols J.L., Bariac T. and Weng P., 2003b. Nitrogen dynamics in the shallow groundwater of a riparian wetland zone of the Garonne, Southwester France: nitrate inputs, bacterial densities, organic matter supply and denitrification measurements. Hydrol. Earth Sci. Syst., 7, 97-107.

Sánchez-Pérez J.M., Gerino M., Sauvage S., Dumas P., Maneux E., Julien F., Winterton P. and Vervier P., 2009. Effects of nutrient pollution on in-stream nutrient retention in an agricultural watershed. Ann. Limnol. - Int. J. Limnol., 45, 79-92.

Schmid P.E. and Schmid-Araya J.M., 2010. Scale-dependent relations between bacteria, organic matter and invertebrates in a headwater stream. Fundam. Appl. Limnol., 176, 365-375.

Sebilo M., Billen G., Grably M. and Mariotti A., 2003. Isotopic composition of nitrate-nitrogen as a marker of riparian and benthic denitrification at the scale of the whole Seine river system. Biogeochemistry, 63, 35-51.

Sinsabaugh R.L., Antibus R.K., Linkins A.E., McClaugherty C.A., Rayburn L., Repert D. and Weiland T., 1993. Wood 
decomposition - nitrogen and phosphorous dynamics in relation to extracellular enzyme activity. Ecology, 74, $1596-1593$.

Stanford J.A. and Ward J.V., 1988. The hyporheic habitat of river ecosystems. Nature, 335, 64-66.

Strayer D.L., 2010. Alien species in fresh waters: ecological effects, interactions with other stressors, and prospects for the future. Freshwat. Biol., 55 (Suppl. 1), 152-174.

Taleb A., Belaidi N., Sanchez-Perez J.M., Vervier P., Sauvage S. and Gagneur J., 2008. The role of the hyporheic zone in the nitrogen dynamics within a semi-arid gravel bed stream located downstream of a heavily polluted reservoir (Tafna wadi, Algeria). River Res. Appl., 24, 183-196.

Thompson R.C., Moschella P.S., Jenkins S.R., Norton T.A. and Hawkins S.J., 2005. Differences in photosynthetic marine biofilm between sheltered and moderately exposed rocky shores. Mar. Ecol. Prog. Ser., 296, 53-63.

Tockner K., Ward J.V., Edwards P.J. and Kollmann J., 2002. Riverine landscapes: an introduction. Freshwater Biol., 47, 497-500.

Tonina D. and Buffington J.M., 2009. Hyporheic Exchange in Mountain Rivers I: Mechanics and Environmental Effects. Geogr. Compass, 3, 1063-1086.

Tringe S.G., von Mering C., Kobayashi A., Salamov A.A., Chen K., Chang H.W., Podar M., Short J.M., Mathur E.J., Detter, J.C., Bork P., Hugenholtz P. and Rubin E.M., 2005. Comparative metagenomics of microbial communities. Science, 308, 554-557.

Valett H.M., Morrice J.A., Dahm C.N. and Campana M.E., 1996. Parent lithology, groundwater-surface water exchange and nitrate retention in headwater streams. Limnol. Oceanogr., 41, 333-345.

Vandenkoornhuyse P., Dufresne A., Quaiser A., Gouesbet G., Binet F., Francez A.J., Mahé S., Bormans M., Lagadeuc Y. and Couée I., 2010. Integration of molecular functions at the ecosystemic level: breakthroughs and future goals of environmental genomics and post-genomics. Ecol. Lett., 13, 776-791.
Vervier P., Bonvallet-Garey S., Sauvage S., Maurice V. and Sánchez-Pérez J.M., 2009. Influence of the hyporheic zone on the phosphorus dynamics of a large gravel bed river, Garonne river, France. Hydrol. Process., 23, 18011812.

Ward J.V. and Voelz N.J., 1994. Groundwater fauna of the South Platte River system, Colorado. In: Gilbert J., Danielopol D.L. and Stanford J.A. (eds.), Groundwater Ecology, Academic Press, San Diego, 391-423.

Weng P., Sánchez-Pérez J.M., Sauvage S., Vervier P. and Giraud F., 2003. Assessment of the quantitative and qualitative buffer function of an alluvial wetland: Hydrological modelling of a large floodplain (Garonne River, France). Hydrol. Process., 17, 2375-2393.

Werner S. and Rothhaupt K.O., 2007. Effects of the invasive bivalve Corbicula fluminea on settling juveniles and other benthic taxa. J. N. Am. Benthol. Soc., 26, 673680 .

Williams D.D. and Hynes H.B.N., 1974. The occurrence of benthos deep in the substratum of a stream. Freshwater Biol., 4, 233-256.

Williams D.D. and Hynes H.B.N., 1976. The recolonization mechanisms of stream benthos. Oikos, 27, 265-272.

Williams J.B., Mills G., Bamhurst D., Southern S. and Garvin N., 2009. Transport and degradation of a trichloroethylene plume within a stream hyporheic zone. Proc. 2007 Nat. Conf. Environ. Sci. Tech., 4, 189-194.

Woessner W.W., 2000. Stream and fluvial plain ground water interactions: rescaling hydrogeologic thought. Ground Water, 38, 423-429.

Wood P.J., Gunn J., Smith H. and Abas-Kutty A., 2005. Flow permanence and macroinvertebrate community diversity within groundwater dominated headwater streams and springs. Hydrobiologia, 545, 55-64.

Wood P.J., Boulton A.J., Little S. and Stubbington R., 2010. Is the hyporheic zone a refugium for macroinvertebrates during severe low flow conditions?Fundam. Appl. Limnol., 176, 377-390. 